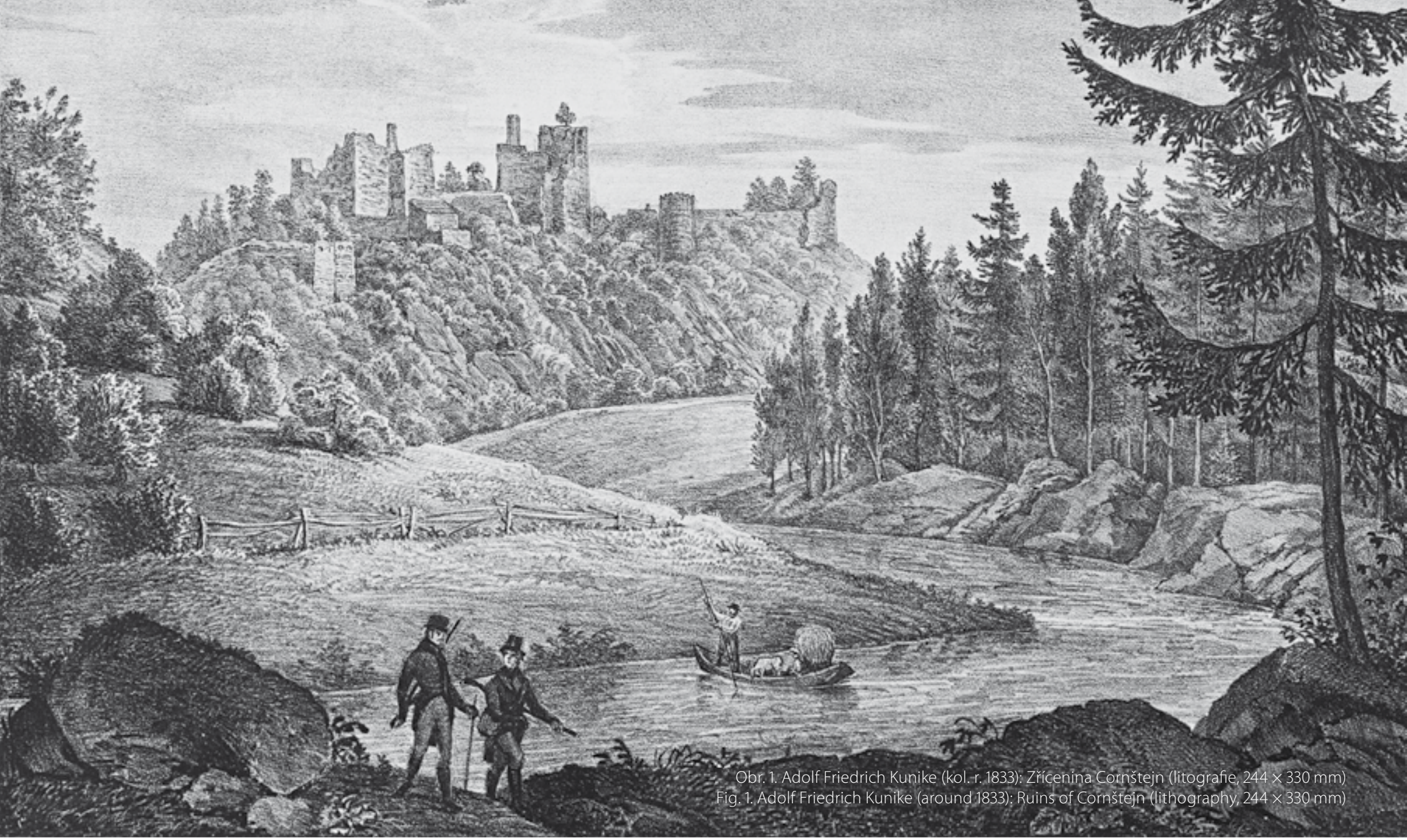

\title{
Vodní nádrže a jejich krajina ve výtvarném umění
}

\section{JAN LACINA, PETR HALAS}

Klíčová slova: krajinomalba - přehrady - změny krajinných struktur

\section{SOUHRN}

Jedním ze základních směrů krajinné ekologie je hodnocení změn krajiny prostřednictvím srovnání jejího stavu (využití) v různých časových obdobích K tomuto účelu se běžně používají mapy, fotografie, letecké i družicové snímky. Významným podkladem pro krajinně ekologickou interpretaci však mohou být i malî́ská a grafická zobrazení krajiny, pokud jsou ovšem dostatečně realistická. Právě výstavba přehrad patři k těm lidským zásahům, které mění krajinu nejvíce. Prritom před zatopením se údolní i nivní poříční krajina zpravidla vyznačovala obzvláště pestrou a malebnou krajinnou mozaikou, která lákala malî́e k zobrazení více než jiná území. Typickým príkladem jsou údolí řek Dyje a Želetavky na jihozápadní Moravě, která byla ve 30. letech 20. století z části zatopena vodami Vranovské přehrady. Již od začátku 19. století tuto romantickou krajinu zobrazovala řada rakouských i českých malířu, kteří zachytili často velmi podrobně - její podstatné rysy. K posouzení změn je tak k dispozici obsáhlý soubor krajinomaleb i grafických listů, zejména litografií, deponovaný $\checkmark$ Jihomoravském muzeu ve Znojmě. Kromě Vranovské přehrady se článek zabývá i výtvarnou dokumentací krajiny a výstavby údolní nádrže Vír na řece Svratce, vltavské přehradní kaskády a vodního díla Nové Mlýny na jižní Moravě. Okrajově je věnována pozornost i výtvarné výzdobě přehradních objektů. 


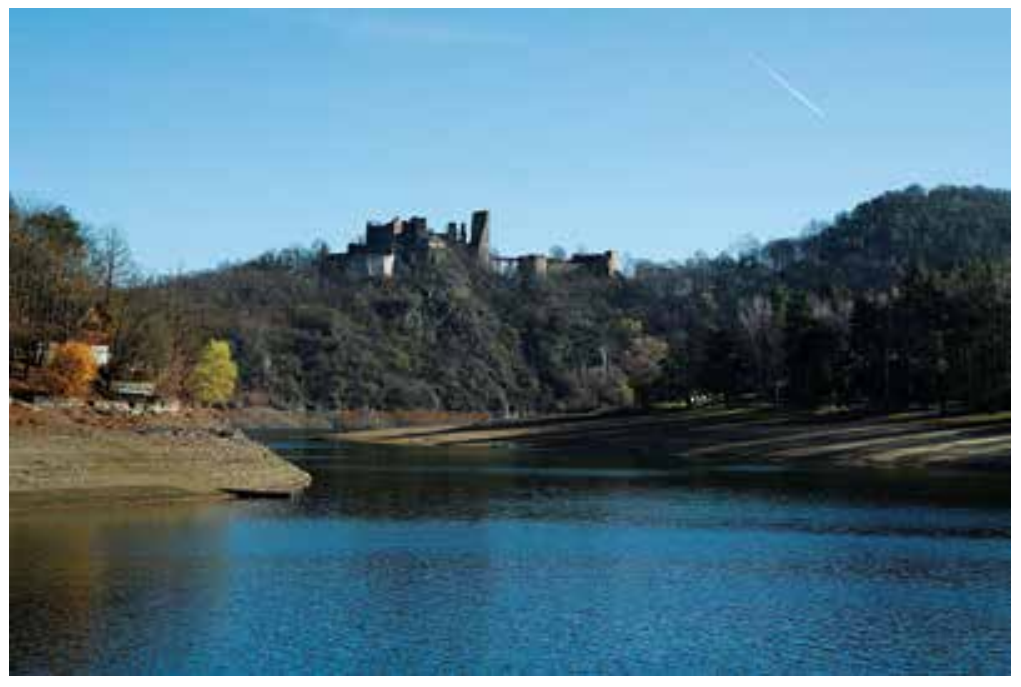

Obr. 2. Zrícenina Cornštejna v roce 2015

Fig. 2. Ruins of Cornštejn in 2015

\section{ÚVOD}

Území, ve kterých bývají budovány přehradní nádrže, patři zpravidla k nejzajímavějším a nejpřitažlivějším částem krajiny. Zaříznutá údolí řek totiž vynikají nejen bohatstvím rostlinných a živočišných druhů a jejich společenstev, ale i tvary reliéfu včetně výchozů rozmanitých hornin. Vysokou biodiverzitou a geodiverzitou se vyznačují i nížinné nivy, pokud jsou v nich alespoň částečně zachovány přirozené fluviální procesy. Zmíněné pořiční krajiny tedy bývají výjimečné bizarní mozaikou krajinných, zejména vegetačních, struktur. Proto jsou předmětem zvýšeného zájmu nejen prírodovědců rozmanitých specializací a ochránců prírody a krajiny, ale i maliřů. Dá se říci, že ekologické hodnoty krajiny podmiňují její kvality estetické. Vodní nádrže vždy znamenají velmi citelný zásah do krajinných struktur, zánik určitých společenstev, změnu krajinného rázu. Krajinomalba, realisticky zachycující stav krajiny před jejím zatopením, tak může být jedním z významných dokumentů a podkladů pro krajinně ekologickou interpretaci změn $v$ důsledku realizace vodních děl. Takovéto využití krajinomalby je hlavním tématem tohoto pojednání.

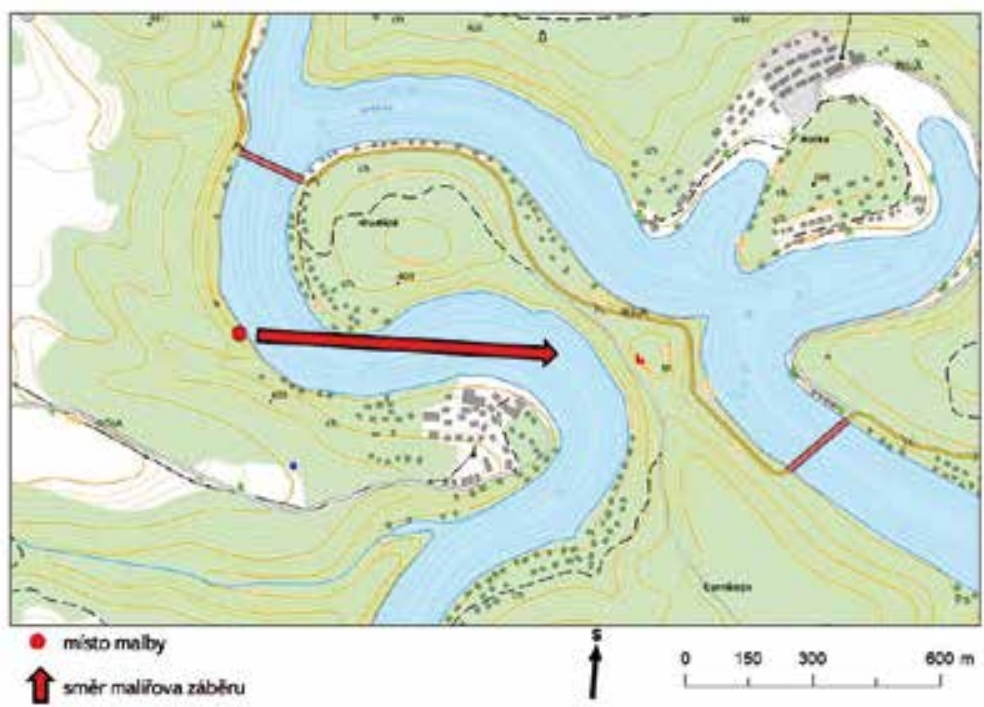

Obr. 3. Místo a směr malírova záběru

Fig. 3. The place and direction of the painter's shot

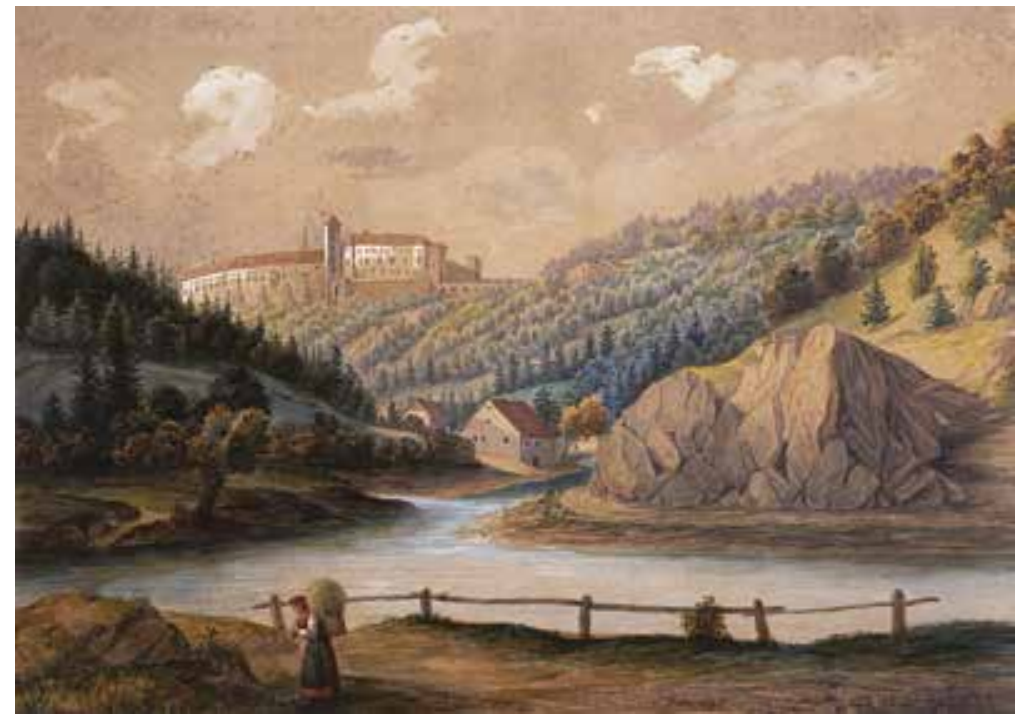

Obr. 4. Josef Doré (1865): Hrad Bítov (akvarel, $325 \times 458$ mm)

Fig. 4. Josef Doré (1865): Bítov Castle (watercolor, $325 \times 458 \mathrm{~mm}$ )

Kromě původních pořičních krajin zachytili malî́ri i budování přehrad. Bylo tak tomu zejména $\vee 50$. letech 20 . století, kdy tehdejší režim striktně vyžadoval angažované umění v duchu socialistického realismu. Nedá se ovšem uprít, že nové vodní hladiny učinily krajinu alespoň pro některé malíre přitažlivější, a proto ji pojali jako dominantu svých krajinomaleb. A nelze, alespoň okrajově, nezmínit, že výstavba některých prehrad vyvolala i zajímavou výtvarnou výzdobu svých doprovodných objektů.

\section{LITERÁRNÍ PŘEHLED}

K běžným metodám studia plošných změn krajiny patři interpretace starých map. Přibližně v posledních 15 letech se staly i veřejnosti poměrně dostupné mapy vojenských mapování - I., II. a III. - z let 1764-1768, 1836-1852 a 1876-1880 v měřítku $1: 28$ 000, resp. $1: 70$ 000. Výhodou topografických map středních měřitek je jejich využitelnost pro studium změn větších územních celků [1-3]. Kromě zmíněných map vojenského mapování Ize z pozdějších období využít československé topografické mapy z 50. a 90. let 20. století a současné základní

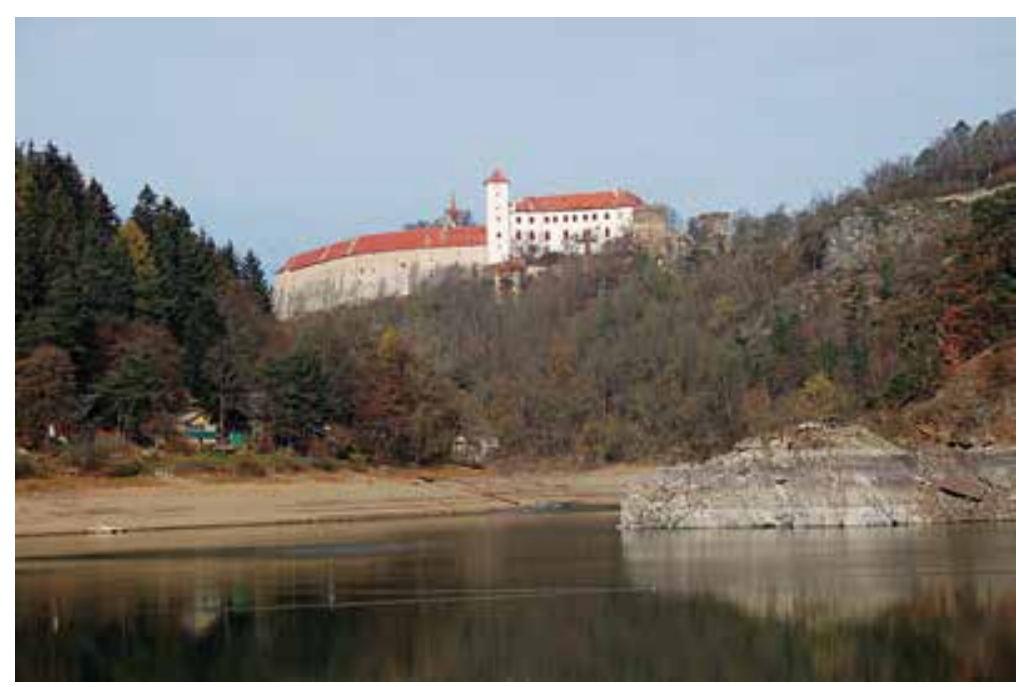

Obr. 5. Hrad Bítov v roce 2015 (fotografie: J. Ptáček)

Fig. 5. Bítov Castle in 2015 (photo: J. Ptáček) 


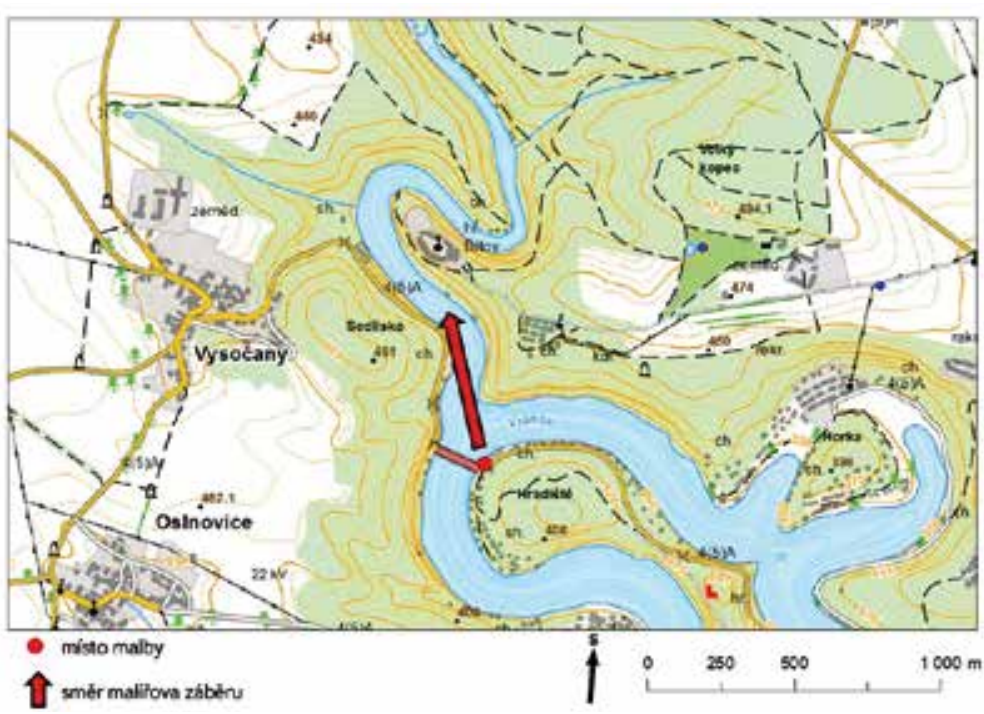

Obr. 6. Místo a směr malírova záběru

Fig. 6. The place and direction of the painter's shot

mapy České republiky. Zkušenosti se zpracováním starých map prezentovali odborní pracovníci Výzkumného ústavu Silva Taroucy pro krajinu a okrasné zahradnictví, v. v. i., na př́kladu administrativně i prírodně vymezených území, např. v krajích, okresech, obcích s rozšířenou působností, geomorfologických regionech, povodích a chráněných územích [4-10].

Krajinní a vegetační ekologové často zkoumají vztah změn využívání krajiny a změn biodiverzity [11-13], zaobírají se dlouhodobými změnami využívání krajiny ve velkých prostorových měřítcích, např. [14], v České republice např. [15].

Svérázným a zatím jen málo využívaným prístupem ke studiu změn krajiny s ohledem na vegetaci a floru je využití zobrazení krajiny a jejích detailů na starých fotografiích, skicách a zejména v krajinomalbách i v kresebných a grafických dílech.

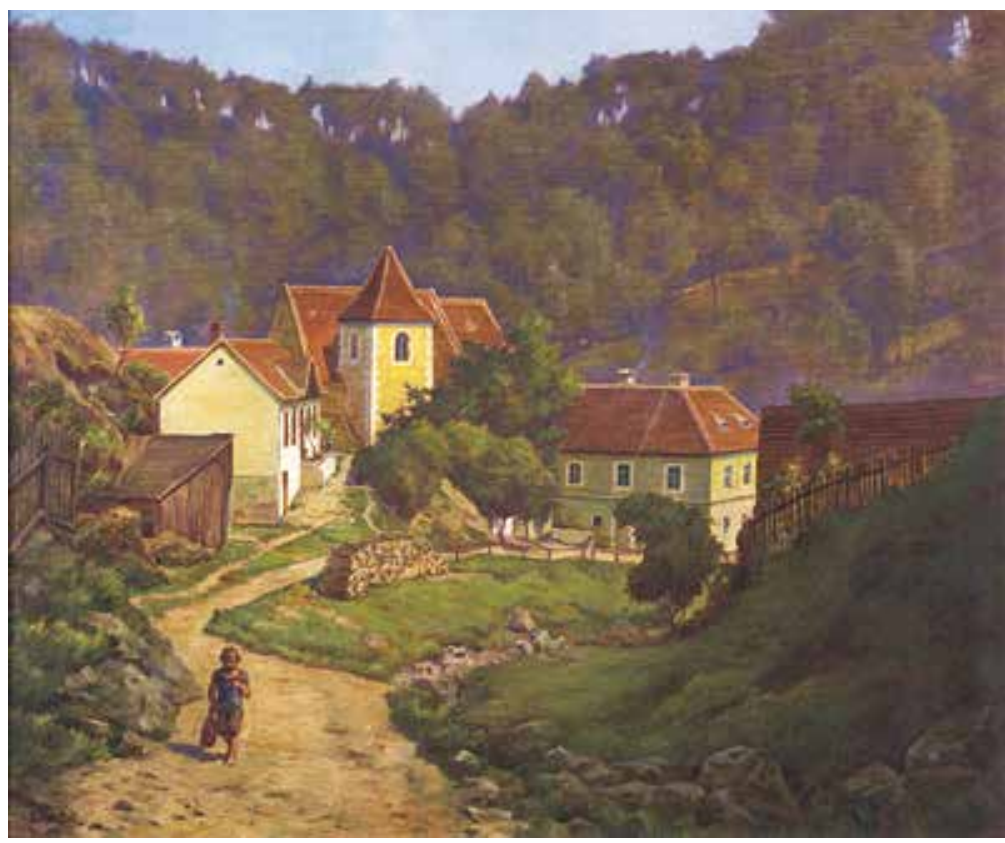

Obr. 7. Oskar Slavíček (1932): Kostel sv. Václava ve starém Bítově (olej na plátně, 50 ×60cm) Fig. 7. Oskar Slavíček (1932): Church of St. Wenceslas in old Bítov (oil on canvas, $50 \times 60$ cm)

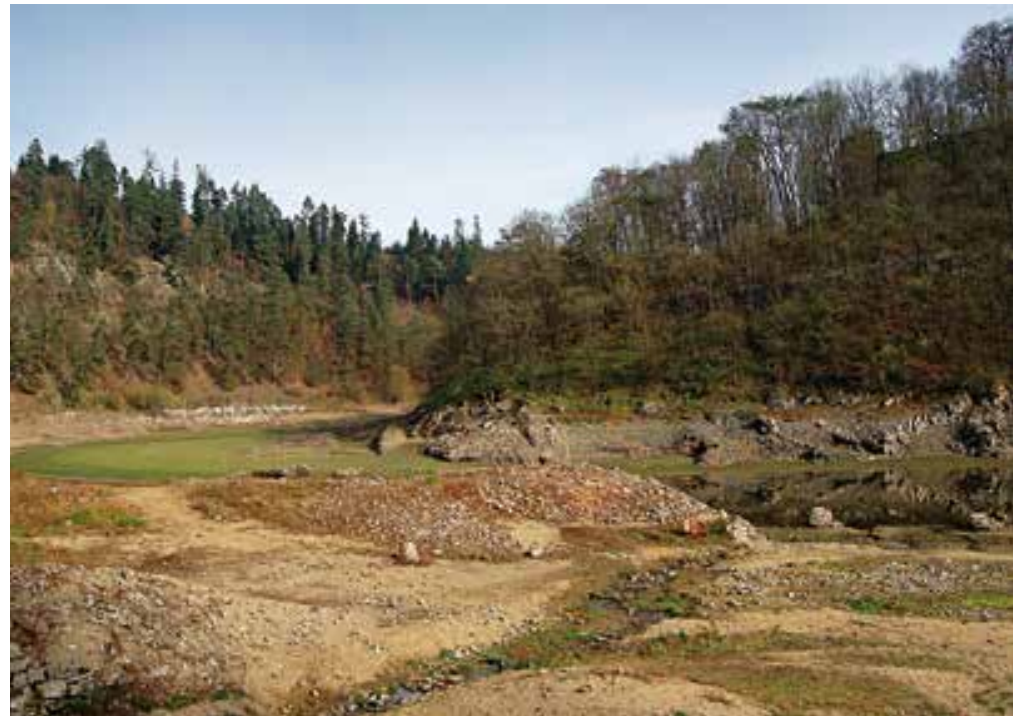

Obr. 8. Základy kostela sv. Václava ve starém Bítově v roce 2015 (fotografie: J. Ptáček) Fig. 8. The foundations of the St. Wenceslas in old Bítov in 2015 (photo: J. Ptáček)

O interpretaci starých pramenů pro potřeby změn v krajině - rozmanitých map a skic, historických statistických dat o využití půdy a leteckých snímků obsáhle a podrobně pojednala ve své knize autorka Trpáková [16]. O využití starých krajinomaleb $\mathrm{k}$ témuž účelu je však v tomto díle jen stručná informace. Přitom i krajinomalby, pokud jsou dostatečně realistické, mohou hodnocení změn vegetačního krytu $v$ zobrazené krajině dobře posloužit a podložit výstupy mapových analýz. Podle V. V. Štecha je "krajinomalbu možno považovat za zrcadlo změn, jimiž procházel lidský vztah k prírodě a ke světu" [17]. Tento významný historik umění v katalogu výstavy Česká krajina v Alšově jihočeské galerii v Hluboké nad Vltavou též uvádí, že "sledovat vývoj české krajinomalby je vzácnou poutí po našich krajích a dobách. Otevřené oči a vnímavá srdce najdou při ní mnohé poučení nejenom o vzhledu domácí přírody a jejím ovzduší, měnícím se podle ročních dob i postupem věků, nýbrž i závažné zprávy o duchovní atmosféře časů" [18]. O tři desetiletí později Ivan Dejmal v letáku konference a výstavy Tvář naší země - krajina domova píše, že „málo co vypovídá o způsobu našeho života a myšlení tak přesvědčivě jako srovnání minulých obrazů české a moravské krajiny v maliřství a fotografii 19. a 20. století s její současnou tváří." Svou stat přitom příznačně nazval Česká krajina od uklizenosti k vyklizenosti a zpustnutí [19]. Třebaže se jednalo o krajinně ekologickou akci, ke srovnání starých krajinomaleb se současným stavem krajiny v jejich záběru ani na této výstavě nedošlo. Ojedinělým príkladem takového srovnání je katalog výstavy Podyjí ve sbírce Jihomoravského muzea ve Znojmě, v němž několik reprodukcí starých krajinomaleb provází fotografie současného stavu [20].

Krajinomalba na území dnešní České republiky, a to jak v její české, tak i moravsko-slezské části, má více než dvousetletou tradici. Od začátku 19. století se na pražské Akademii výtvarných umění vystřídalo - s prestávkami - několik krajinářských škol - Karla Postla, Antonína Mánesa, Maximiliána Haushofera, Julia Mařáka, Otakara Nejedlého. Vyrostly zde - často s přispěním dalšího školení v cizině (Mnichov, Düsseldorf, Vídeň, Paříž a plenér v Barbizonu) - desítky významných krajinářu. Další krajináři se vyškolili mimo krajinářské ateliery např. Josef Jambor absolvoval Akademii v grafické speciálce Maxe Švabinského, Oldřich Blažiček u figuralisty Hanuše Schwaigera. Pro krajinně ekologickou interpretaci, včetně hodnocení změn vegetačního krytu a flory jakožto ukazatele způsobu a intenzity využití půdy, je tak k dispozici veliké množství děl z různých krajinných typů i časových horizontů [21-25].

Krajinomalbou ve vztahu k přehradním nádržím Vranov a Nové Mlýny se věnovali autoři této statě v letech 2014-2016 při řešení projektu NAKI Zatopené kulturní a prírodní dědictví jižní Moravy [26]. 


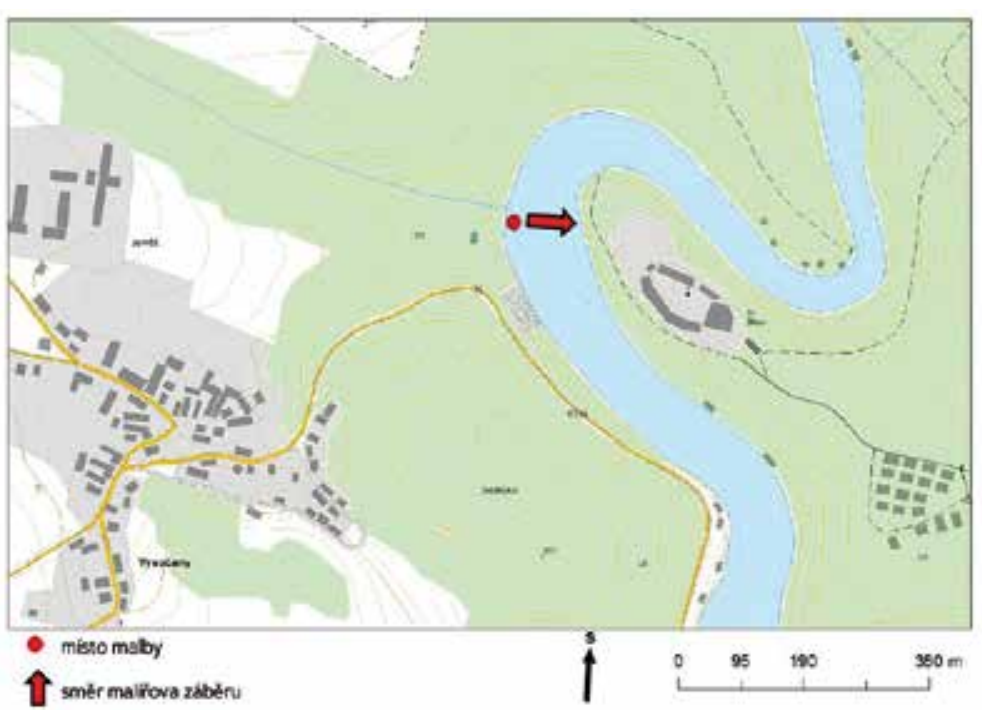

Obr. 9. Místo a směr malířova záběru

Fig. 9. The place and direction of the painter's shot

\section{METODICKÝ PŘÍSTUP}

Metodický prístup spočívá ve srovnání staré krajinomalby z období před záplavou se současným stavem přehradní krajiny. Prvním krokem je výběr vhodných děl krajinomalby (ve stálých galerijních expozicích, depozitárích galerií a muzeí, na krátkodobých výstavách, v monografích či v katalozích) a pořízení jejich reprodukcí. Poté se pomocí topografické mapy předběžně odhadne místo maliřova záběru, které se pak co nejpřesněji dohledá v terénu. Pořídí se srovnávací fotodokumentace současného stavu - celkový záběr obrazu, zachycující změnu krajinného rázu, i detaily, vystihující změny reliéfu a vegetačního krytu. Následuje zhotovení podrobné mapky místa a směru maliřova záběru a popis změn.

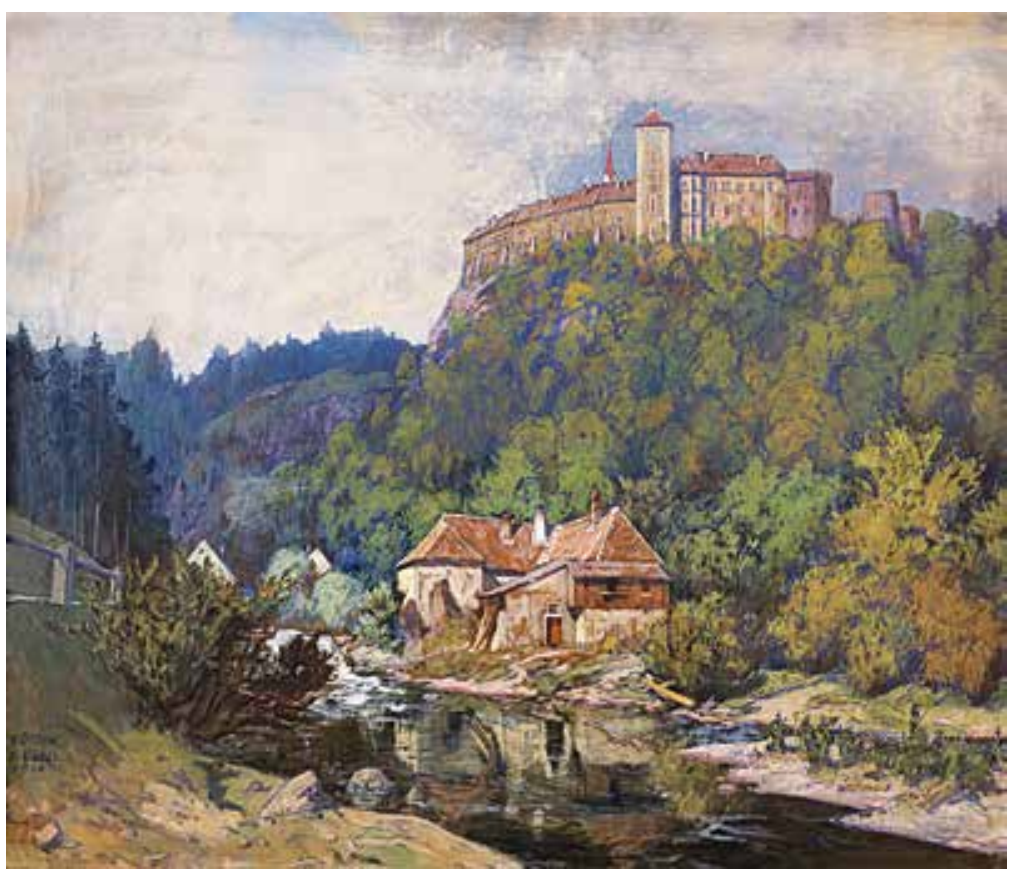

Obr. 10. Karl Gödel (1910): Želetavka pod Bítovem (tempera, $61 \times 71 \mathrm{~cm}$ )

Fig. 10. Karl Gödel (1910): The Želetavka River under the Bítov Castle (tempera, $61 \times 71 \mathrm{~cm}$ )

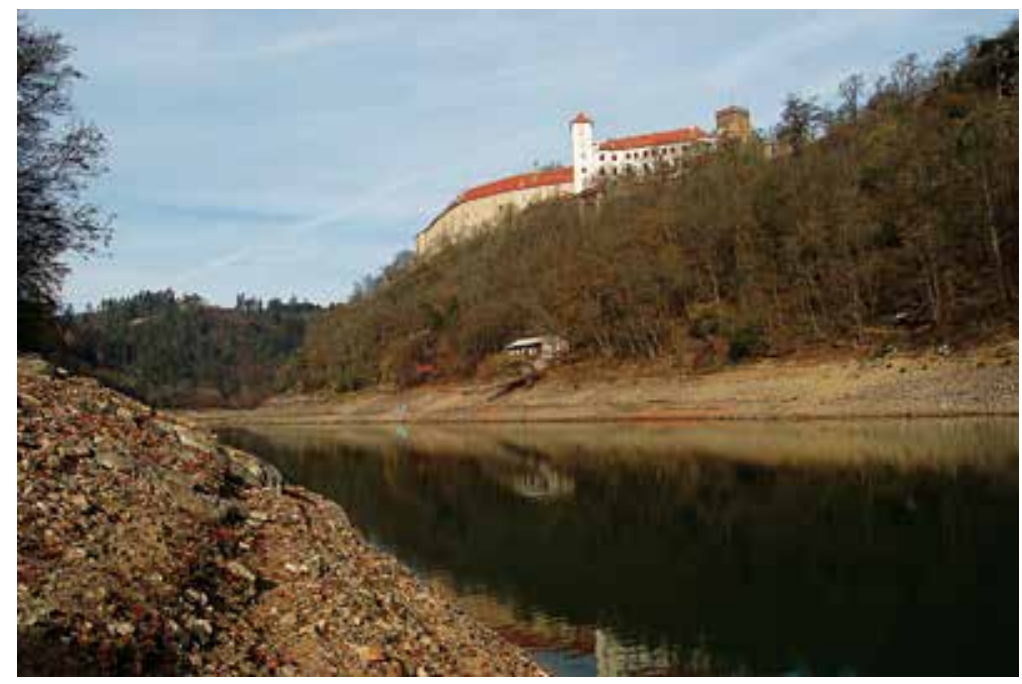

Obr. 11. Pohled na hrad Bítov v roce 2015 (fotografie: J. Ptáček)

Fig. 11. View of Bítov Castle in 2015 (photo: J. Ptáček)

\section{VÝSLEDKY}

\section{Krajinomalba jako výtvarný dokument krajiny před výstavbou přehrad}

K malî̌rsky nejfrekventovanějším patřilo údolí Dyje od Znojma přes Vranov až nad rakouský Drosendorf Stadt. Romantické údolí na rakousko-moravském pomezí, které mělo být - aniž to maliři tušili - $v$ budoucnu z části zaplaveno vodami Vranovské přehrady, vábilo již v průběhu 19. století (označovaného jako hlavní století krajinomalby) mnohé malî̌re jak z rakouské, tak i moravské strany tehdejšího mocnářství. I na výtvarných dílech z Podyjí můžeme sledovat, jak krajinomalba spěla od romantismu s realistickými prvky k realismu, ale zároveň i k hlubšímu vyjádření umělcových pocitů a prožitků ze zobrazované krajiny. $\checkmark$ prípadě území dnešní Vranovské přehrady je to linie od malî́e a rytce francouzského původu Josefa Doré (1805-1878) přes absolventa krajináŕské školy Maxe Haushofera na pražské akademii, hrotovického rodáka Františka Bohumila

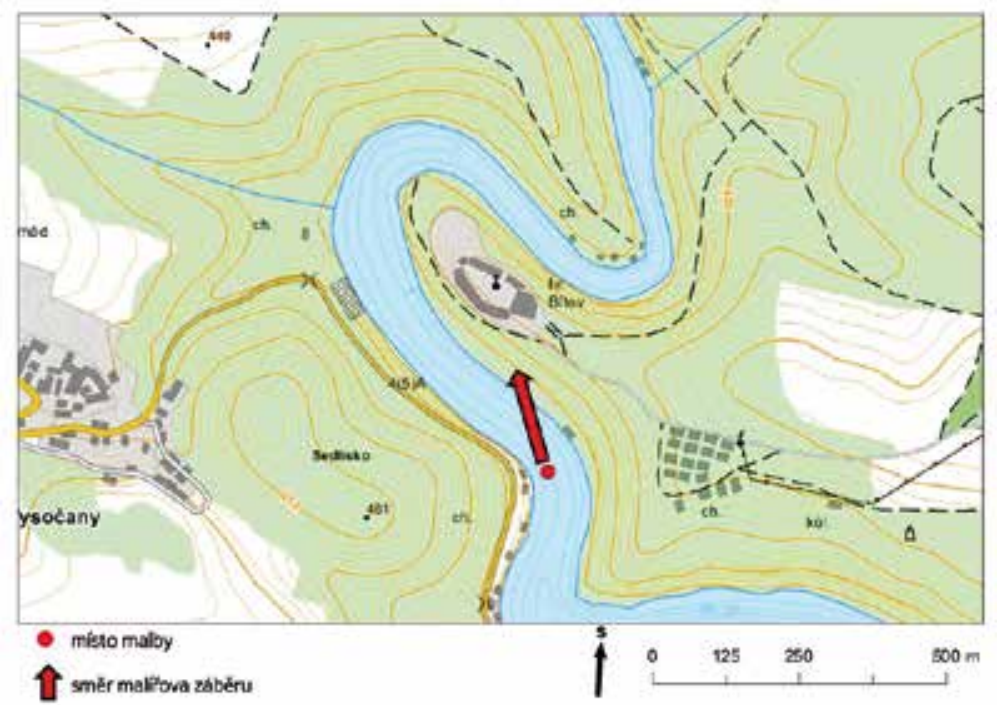

Obr. 12. Místo a směr malírova záběru

Fig. 12. The place and direction of the painter's shot 
Zvěřiny (1835-1908) až po absolventa Mařákovy školy Romana Havelku (1877-1950). Ten, jako jediný z klasických krajinárư, ve svém oblíbeném území maloval i po jeho částečném pohřbení vodou, ale tak, aby se pokud možno ve svém záběru přehradou vzduté hladině vyhnul. Obsáhlý soubor děl, zachycující údolní zářez Dyje v průběhu dvou století, je ve sbírkách Jihomoravského muzea ve Znojmě. Všimněme si alespoň některých.

Romantickou a trochu tajemnou atmosféru má litografie Zřícenina Cornštejn (obr. 1) rakouského malî́re A. F. Kunikeho (1777-1838). Zachycuje v ní kolem roku 1833 - v pohledu na východ proti proudu řeky - meandr Dyje a nad ním rozsáhlé zříceniny středověkého hradu Cornštejna. Nad strmým skalnatým břehem jsou stráně zalesněny smíšenými porosty, kdežto mírnější príbřeží protější je kryto louk a pastvin. Záběr oživuje stafáž dvou myslivců v popředí a sedlák převážející na lod'ce přes Dyji seno a kozu.

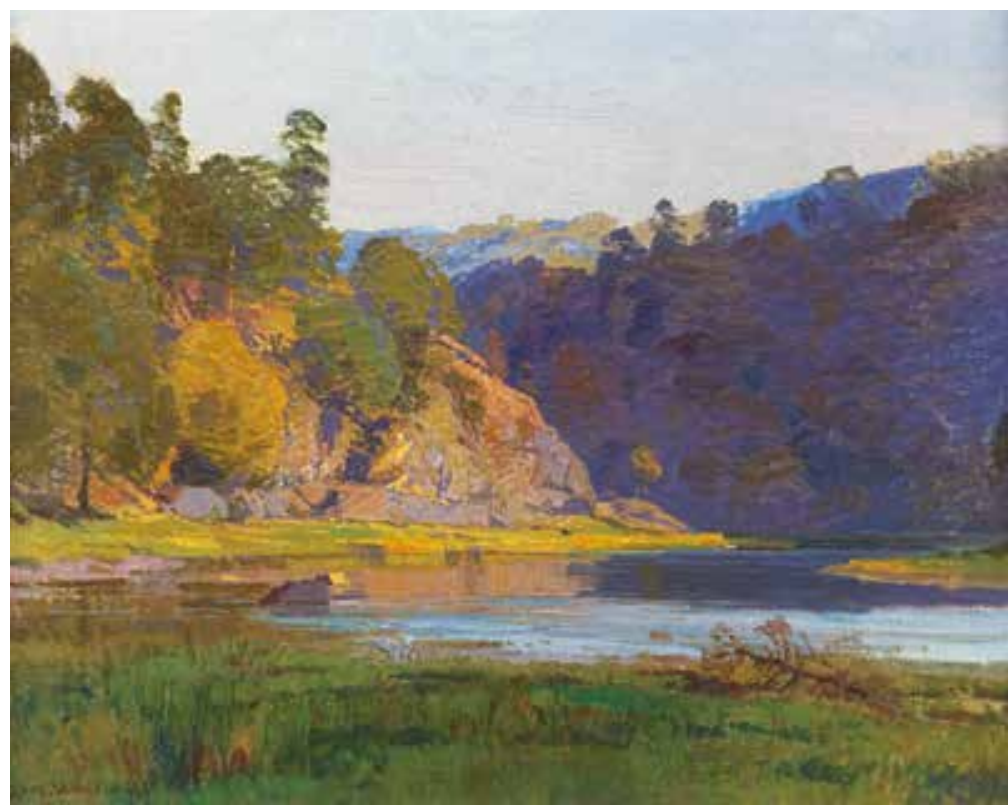

Obr. 13. Roman Havelka (kol. r. 1930): Podzim na Bítově (olej na plátně, $41 \times 51$ cm)

Fig. 13. Roman Havelka (kol. r. 1930): Autumn in Bítov (oil on canvas, $41 \times 51 \mathrm{~cm}$ )

Vody Vranovské prehrady pohřbily tuto starosvětskou idylu jen částečně (obr. 2 a 3), zcela zde však zanikly polokulturní květnaté louky. Hlavní změna spočívá v tom, že do kdysi klidného údolí mezi Bítovem a Cornštejnem vtrhla po obou březích vzduté Dyje rekreační zástavba - doslova chata na chatě. Téměř nedotčeny zůstaly naštěstí na strmých skalnatých svazích pod zříceninou přirozeně rozvolněné a zakrslé listnaté porosty se vzácnou teplomilnou flórou a faunou. Patří k nejcennějším částem evropsky významné lokality Údolí Dyje, vymezené zde v rámci projektu Evropské unie NATURA 2000.

Josef Doré (1805-1878), malîr, kreslîr a rytec francouzského původu, se usadil ve Vranově nad Dyjí kolem roku 1830. Za čtyři desetiletí svého života zde vytvořil maliřskými i grafickými technikami obsáhlé dílo, které patří k nejcennějším výtvarným dokumentům tvárnosti romantického údolí Dyje v 19. století. Akvarel Hrad Bítov z roku 1865 (obr. 4) je malován přes ústí Želetavky do Dyje a zachycuje i spodní konec původního městečka Bítov. Z akvarelu je ž̌ejmé, že strmé svahy hradního kopce měly tehdy spíše úpravu prírodního parku - kulisy listnatých dřevin i uměle vysázeného smrku střídají zatravněné pruhy. Nad skaliskem při ústí je výsadba dřevin jen roztroušená, pod skálou těsně vede jedna z prrístupových cest do městečka. Stafáž ženy s nưší trávy v popredí nasvědčuje, že píce se často nosila do Bítova zdaleka.

Místo prašné cesty $\vee$ popředí Dorého záběru je dnes (obr. 5 a 6) asfaltovaná silnice $s$ novým mostem, silně frekventovaná zejména v letním období. Vranovskou přehradou o několik metrů vzdutá Želetavka a Dyje zaplavují ve

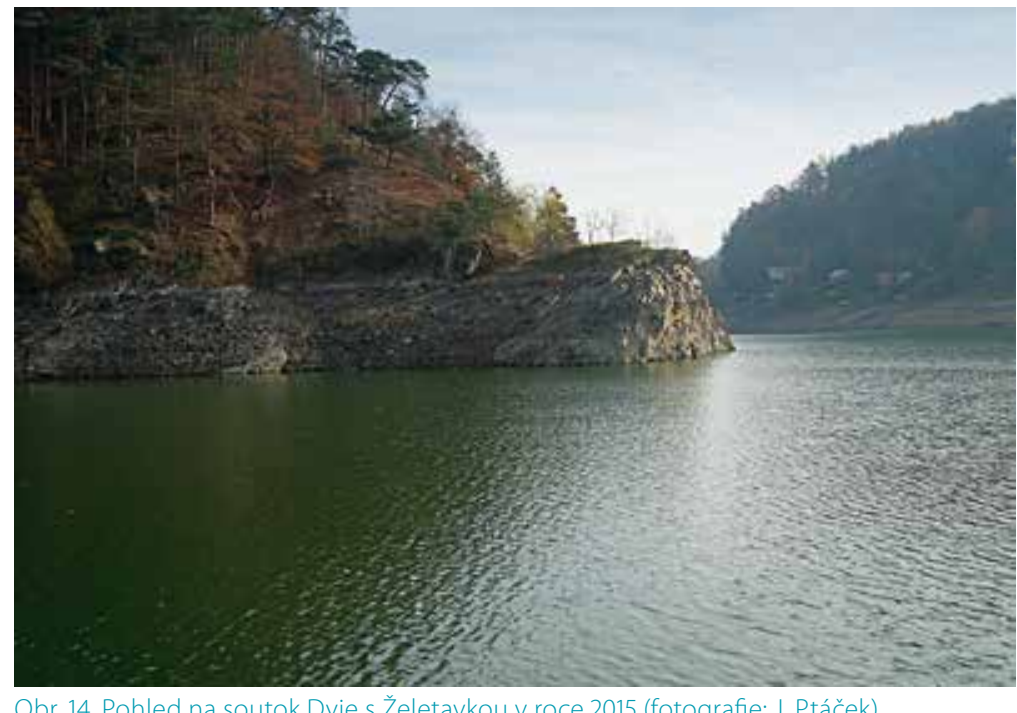

(j) Ptáček)

Fig. 14. View of the confluence of the rivers Dyje and Želetavka in 2015 (photo: J. Ptáček)

srážkově normálních letech do poloviny skály v popředí. Místo zaniklé spodní části Bítova je zde v pravobřeží vzduté Želetavky mezi novou silnicí a přehradní hladinou natěsnána chata na chatě. Jen ten hrad na obzoru trčí stále stejně, strmé svahy pod ním i před ním jsou však zalesněny souvisle.

Oskar Slavíček (1879-1951), učitel v Suchohrdlích u Znojma, byl i dobrým malířem. Jeho olejomalba Kostel sv. Václava ve starém Bítově z roku 1932 (obr. 7) je kvalitním a cenným výtvarným dokumentem centrální části zaniklého Bítova. Městečko se táhlo v délce necelého kilometru podél Želetavky pod ostrožnou se stejnojmenným hradem. Malír je zachytil - velmi idylicky - nedlouho před jeho likvidací. Po roce 1934 sem zasáhlo vzdutí Vranovské přehrady, z Bítova zůstal jen hřbitov, lokalizovaný na terase strmého svahu nad zátopou.

V extrémně suchém roce 2015 poklesla hladina přehrady natolik, že byly obnaženy zbytky základového zdiva kostela i okolních stavení (obr. 8 a 9). Nebýt letitých sedimentů, vypadal by zde spodní tok Želetavky téměř stejně jako před napuštěním přehrady.

Ve srovnání s podobným záběrem Josefa Doré se přibližil rakouský malî̌r Karl Gödel (1870-1948) ve svém obraze Želetavka pod Bítovem (1910) ke hradu Bítovu proti proudu Želetavky o pár set metrů (obr. 10). Jeho záběr tak minul skalní ostrožnu nad ústím Želetavky do Dyje, zato zachytil v popředí obrazu starosvětský mlýn se zpěněným jezem na spodním konci městečka. Na rozdíl od o půlstoletí staršího zobrazení J. Dorého vedla již do údolního sídla silnice - svědčí o tom Gödlem namalované betonové zábradlí těsně nad Želetavkou při levém okraji obrazu.

Mlýn - obdobně jako celé městečko Bítov - zanikl v zátopě Vranovské přehrady, silnice byla přeložena výše (obr. 11 a 12). Současná chatová zástavba v úzkém pruhu mezi silnicí a přehradní hladinou má k idyle té tradiční před sto lety hodně daleko!

Roman Havelka (1877-1950) byl jedním z nejmladších a posledních absolventů slavné krajinářské školy Julia Mařáka na pražské Akademii výtvarných umění. Pocházel sice z Jemnice, ale romantické údolí Dyje ho ohromilo již v jinošských letech a stalo se jeho malírským údělem. Autor Uhlîr [27] uvádí, že během svého života vytěžil z Podyjí téměř 3000 krajin, výtečně zachycujících barevné a světelné nálady lesnatých řičních údolí v rưzných obdobích vegetace. Obraz Podzim na Bítově (obr. 13) má i presnější název Ústí Želetavky do Dyje pod Bítovem. Zachycuje osluněné skalisko s prořídlým porostem borovic v levobřeží Želetavky nad ústím ve směru po proudu, kdežto Josef Doré je roku 1865 zachytil z opačné strany, tedy proti proudu. Na Havelkově obrazu ze začátku 30. let minulého století je patrné, že soutok řek byl lemován mokřadními travinnými společenstvy, kontrastujícími s vyprahlou vegetací skal. 
Tento jedinečný kontakt rozmanitých biotopů byl zatopen (obr. 14 a 15). Na současných velmi strmých přehradních březích s kolísající hladinou se mokřadní lem již nevytvoří. Pohled na přehradní hladinu je ve srovnání s maliřovým záběrem velice fádní. Nelze ovšem nepřiznat, že R. Havelka zůstal krajině údolních říčních zářezů pod Bítovem a Cornštejnem věrný i po jejím částečném pohřbení vodou. Maloval zde však tak, aby vzdutou hladinu nebylo príliš vidět.

Výtvarně byla často dokumentována i nivní krajina pod Pálavou, která pak byla v letech 1978-1989 zaplavena třemi nádržemi vodního díla Nové Mlýny. Ve sbírkách Regionálního muzea v Mikulově je pozoruhodný soubor výtvarných děl Wenze Grölla (1889-1969), který muzeu věnovala malírova vnučka Gertruda Gröllová. Tento rodák z vesnice Bavory pod Pálavou vystudoval Vysokou školu užitého umění ve Vídni a od roku 1919 působil v tomto městě jako učitel kreslení. Jihomoravská krajina jeho dětství a mládí byla námětem jeho tvorby po celý život, po roce 1945 ji maloval podle fotografí. Mezi Gröllovými akvarely nechybí ani maliřské záznamy záplav pod Pálavou, v nichž se zrcadlí pro tuto krajinu typické hlavaté vrby.

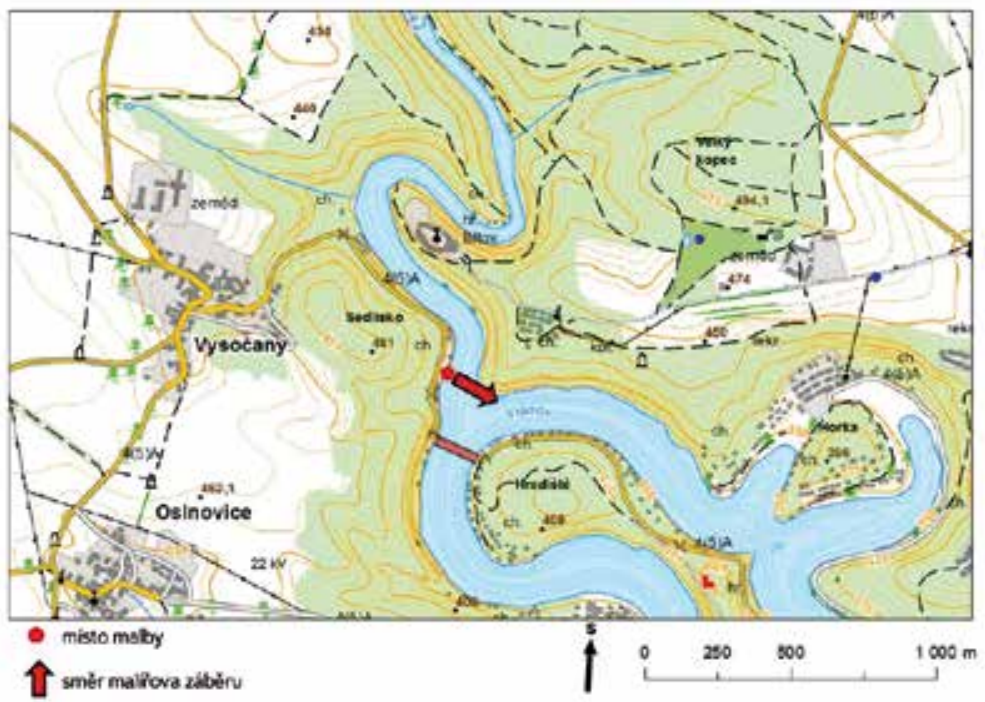

Obr. 15. Místo a směr malírova záběru

Fig. 15. The place and direction of the painter's shot

Za nejsystematičtějšího maliře jižní Moravy Ize považovat Rudolfa Gajdoše (1908-1975), který sice pocházel z Měrína na Českomoravské vrchovině, podstatnou část života však strávil v Lednici a v Mikulově. Absolvent pražské Akademie u Maxe Švabinského a zakládající profesor Školy umění ve Zlíně s láskou zobrazoval především skalnatou a vinorodou Pálavu, vinné sklepy, Mikulov a rybníky kolem Lednice. $V$ jeho díle však najdeme i řadu děl, zachycujících jedinečný kontakt vyprahlého vápencového bradla a mokřadní, periodicky zaplavované dyjské nivy, jak je patrné z monografie, vydané ke Gajdošově mikulovské a brněnské výstavě roku 1973 [28]. Jmenujme alespoň kresby Pálava od Mušova a Pálava od Strachotína (obě z roku 1937), litografii Pálava od Dolních Věstonic (1953) z cyklu Jižní Morava, olejomalby a tempery Letní povodeň u Mušova (1954), Záplavy u Nových Mlýnů (1954), Jarní povodeň pod Pálavou (1956) a Letní záplavy pod Pálavou (1966). „Gajdoš byl přesvědčen, že je nutno zaznamenávat všechny proměny života, zásahy lidí do prrírody a doložit je dílem umělce" vzpomíná na svého př́tele Jan Andrys, bývalý tajemník Sdružení výtvarných umělců moravských v Hodoníně. "Jeden útvar zanikne, vyvstává nový a bude tak i při velkém vodním díle na Dyji... Pracoval tu tedy Gajdoš velmi pilně, o všem byl dobře zpraven, mnoho obrazů rozdělal, aby zachoval, co zajde..." [29]. Byl to zřejmě právě Rudolf Gajdoš, který přivedl na jižní Moravu svého staršího prítele z hodonínského Sdružení výtvarných umělců moravských (SVUM), malíře Vysočiny Josefa Jambora (1887-1964). Z kraje pod Pálavou je uváděno jeho dílo Močály u Mušova (1954).

Stejné území výtvarně dokumentoval i hodonínský malîr Karel Novák (1915-2006) - viz např́klad akvarel Kostel v Mušově (1980), v němž je kostel sv. Leonarda dosud obklopen domky a zahradami vesnice, či olejomalba Letní vody pod Pálavou (1977), zachycující hlavaté vrby nad hladinou letní povodně [30]. Stárnoucí malîr stačil ještě namalovat i trvale zatopené území - např́iklad v olejomalbě Vody Mušovského jezera (1999), zároveň se však nostalgicky vracel ke starým malebným motivưm z období před budováním vodního díla.

Specifickou tajemnou atmosféru lužních lesů a mokřadů pod Pálavou básnivým štětcem vyjádřil Matěj Trojan (1914-1973), poučený dílem Jana Zrzavého, kterému byl v mládí pomocníkem. Trojan patřil k těm nemnoha malír̆ům, kteři pronikli až do nitra mokřadů, kde se mohli opájet samotou v království věkovitých stromů, ptáků, komárů a žab. „Je to právě ona Trojanova romanticky založená obraznost, která mu v jednotlivých dílech dovoluje s prímočarou samozřejmostí spojovat realitu s vizí a snem sklenout v jednotu rousseauovsky naivní vidění světa s kultivovanou maliřskou formou," napsal o Trojanově tvorbě Jiří Hlušička [31]. Již názvy Trojanových obrazů navozují tajemnou a snovou atmosféru dnes již z velké části zaniklých biotopů jihomoravské nivní krajiny - jmenujme alespoň Mysterium lužního lesa I a II (1966 a 1968), Torza starých vrb (1969) a Jezero draků (1971).

Obdobně básnivé je dílo nejen na jižní Moravě velmi oblíbeného Antonína Vojtka (*1934), který je z uvedených malî̌u s divočinou poříční krajiny nejsepjatější a je jí nejvíce okouzlen. Navíc jako někdejší prírodovědně poučený učitel dovede ztvárňované mokřadní a lužní biotopy doplnit o typické druhy rostlin i ptáků - viz například dnes již u nás vyhynulý slanorožec rozprostřený v obraze U Strachotína (1980), kyprej vrbice v díle z cyklu Kraj pod Pálavou (80. léta), invazivní slunečnice hlíznatá v olejomalbě Na konci léta - topinambury (2004). „Mnohá místa, moje místa, pohltila podpálavská jezera" - vyznal se malî́r [32]. Dokáže je však znovu malovat jako vzpomínku, jako sen. Ve Vojtkově díle se i nadále odrážejí kopule vrb s bílými volavkami ve vodách třeba i dávno zaniklého a zřejmě nejkrásnějšího jihomoravského mokřadu Pansee (obr. 16).

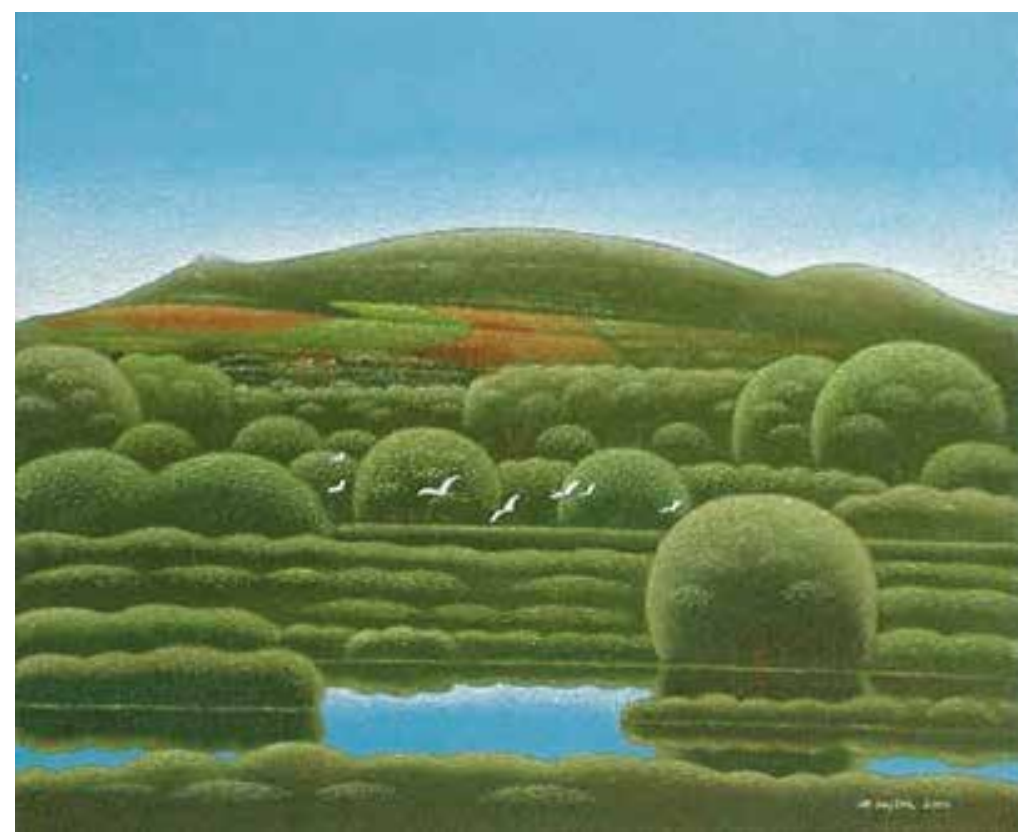

Obr. 16. Antonín Vojtek (2003): Pálavská jezera $(60$ ×50cm), převzato z www.vojtek-av.com Fig. 16. Antonín Vojtek (2003): Lakes under the Pavlov hills $(60 \times 50 \mathrm{~cm})$, taken from www.vojtek-av.com 


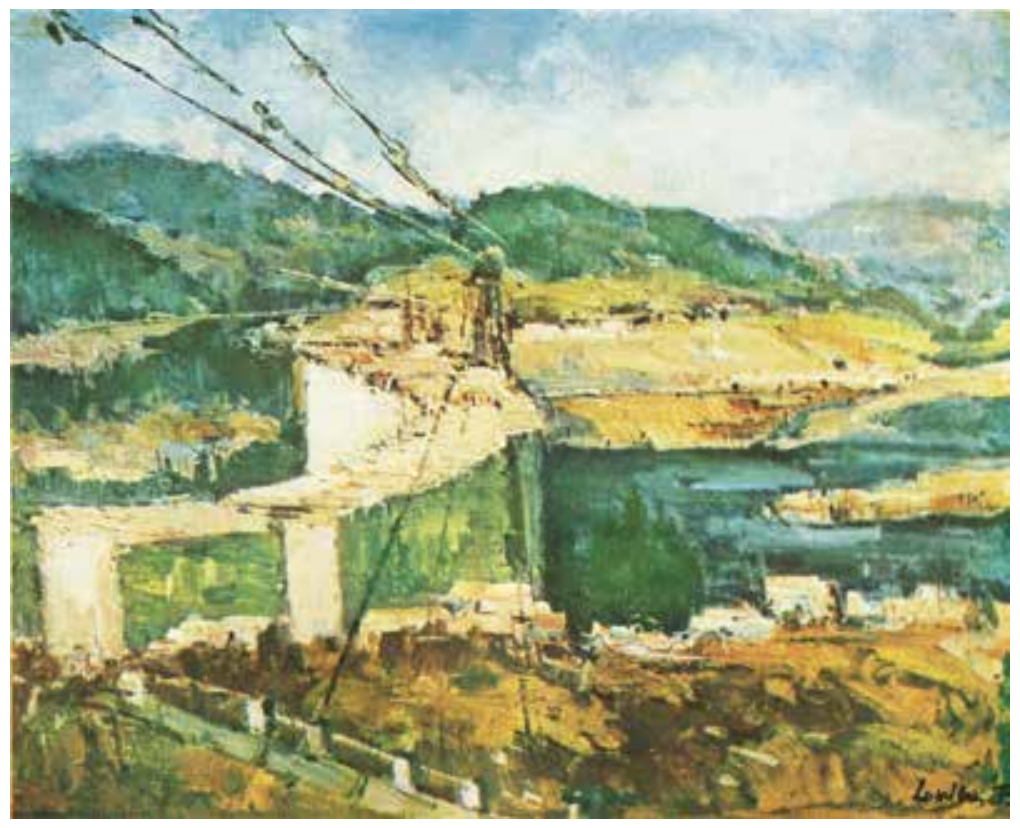

Obr. 17. Alois Lukášek (1950): Stavba Vírské přehrady II. (olej, 65 × 80 cm), převzato z [34] Fig. 17. Alois Lukášek (1950): Construction of the Vír Dam II. (oil, $65 \times 80$ cm), taken from [34]

\section{Výtvarná dokumentace výstavby přehrad}

Nová situace i pro výtvarné umělce nastala po roce 1948, kdy se přehrady staly protežovanými stavbami socialismu a vyžadovanou uměleckou formou byl socialistický realismus neboli sorela. Svědčí o tom katalog Třetí členské výstavy Krajského střediska československých výtvarných umělců v Brně roku 1952. Některé vystavované práce byly - jak v katalogu píše Dr. František Kubišta „výsledkem úkolové akce, při nichž bylo dbáno, aby těžily z budovatelského úsilí, které bylo možno sledovat na stavbě vírské přehrady." [33]. Náročnou přehradní stavbu v hlubokém údolí Svratky nad Vírem začátkem 50. let v různých fázích a z různých pohledů zachytila raada brněnských malîrů - Jan Brukner, Jaroslav Dvořǎček, Eduard S. Kostrhon, František Malý. A také Vojtěch Štolfa (1921-2002), brněnský scénograf a portrétista bylin a trav. Dlužno ovšem dodat, že V. Štolfa ve své olejomalbě Vírské údolí (1952) zachytil stavbu až v pozadí dosud nezatopené lučinaté nivy s kopulemi vrb a s prašnou cestou do Chudobína, vesničky odsouzené k zániku. Jeho obraz je tak spíše než oslavou budovatelského úsilí ojedinělým a kvalitním výtvarným dokumentem vegetačního krytu před zaplavením údolí pár let na to. Naopak jeden z nejplodnějších krajinářů Vysočiny Alois Lukášek (1911-1984), žijící blízko k Víru v Nedvědici, dal ve svých olejomalbách Stavba Vírské přehrady I a II z roku 1950 (obr. 17) betonování hráze dominantní postavení [34].

Podobně, jako se na Moravě věnovali malíri výstavbě údolní nádrže Vír, angažovali se výtvarníci v Čechách v letech 1953-1954 při úkolové svazové akci „Povltaví", tedy při budování vltavské přehradní kaskády. Ochránce prírody a krajiny zaujmou z této akce zejména obrazy Václava Vojtěcha Nováka (1901-1969). Známý malî̌ panoramaticky rozmáchlých záběrů jihočeské rybniční krajiny v olejomalbě VItava u Županovic (1953) a dalších věrně zachytil skalnaté a vegetačně zajímavé údolí Vltavy, které pak roku 1957 zmizelo v záplavě nádrže Slapy. Kdežto malîr sociálních motivů a zadumaných krajin městské periferie Karel Holan (1893-1953) maloval na sklonku svého života například v obraze Přehrada (1952) rozestavěnou přehradní hráz.

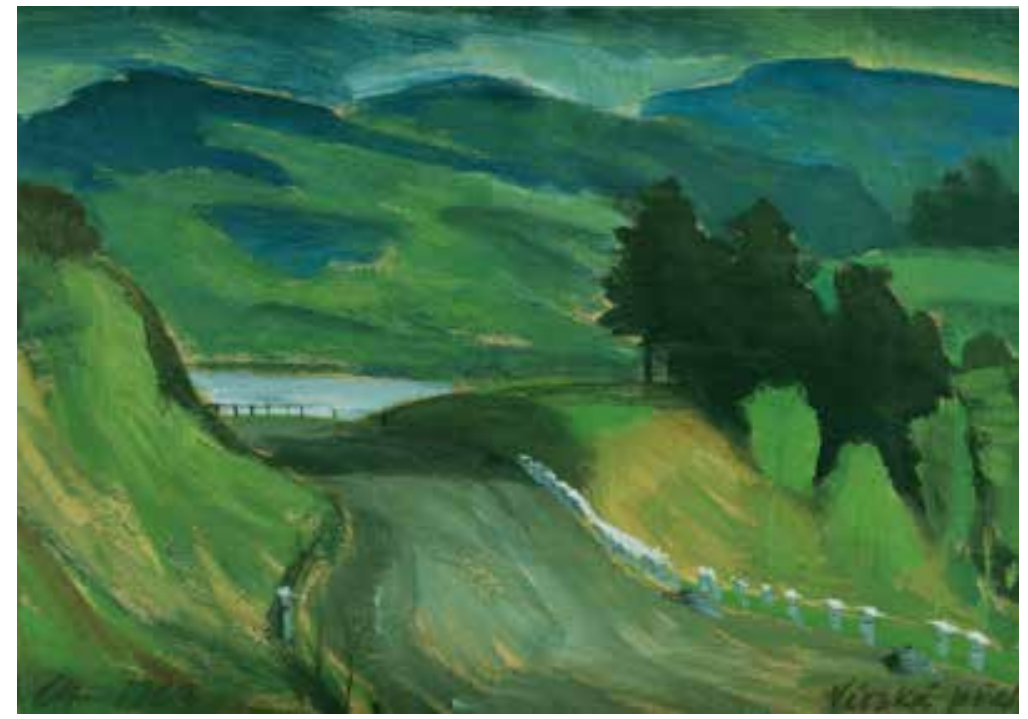

Obr. 18. Jindřich Chmelař (1962): Vírská přehrada (pastel, $30 \times 22$ cm)

Fig. 18. Jindřich Chmelař (1962): Vír Dam (pastel, $30 \times 22 \mathrm{~cm}$ )

\section{Přehradní nádrže jako hlavní motiv krajinomalby}

Jistě není překvapením, že kromě budování prehrad malíríi zobrazovali - a dodnes zobrazují - i hotová přehradní jezera. Jejich hladiny jsou výtvarně zajímavé a lákavé. Třeba hladina Brněnské (dřive Kníničské) přehrady, dokončené roku 1940. „Mám za to, že snad všichni malíri žijící v Brně, kterým učaroval jako projev životního postoje fenomén KRAJINA, alespoň jednou se o přehradu pokusili," píše ve svých obsáhlých vzpomínkách Brno - černá bílá [35] brněnský výtvarník Jan Rajlich. A jmenuje celou řadu malířu i malířek. Vyberme z nich alespoň Miroslava Netíka (1920), který se ve svém obsáhlém díle vracel k Brněnské přehradě nejčastěji - od „budovatelské" olejomalby Sázení stromků na Kníničské přehradě (1952) až po nedostižně svižné akvarely z 60. a dalších let, např. Přístav (1965). Z dalších slavných tvưrců se v souvislosti s přehradou u Brna objevuje dokonce i František Foltýn (1891-1976), proslulý především svými abstraktními kompozicemi. V olejomalbě Přehrada (1951) však spíše realisticky zachycuje výletní lod' pod Hůrkou u Bystrce.

Vírskou přehradu v Hornosvratecké vrchovině, připomínající skandinávská jezera, opakovaně maloval již zmíněný Alois Lukášek a řada regionálních maliřru. Ale také třeba i dendrolog docent Jindřich Chmelař (1926-2001), přední evropský znalec vrb (rodu Salix spp.), který často spolupracoval s vodohospodári na volbě vhodných dřevin při ozeleňování přehrad. Byl též výborným malírem, jak dokumentuje i jeho pastel z roku 1962 Vírská prehrada (obr. 18).

Dominantní postavení v krajině jihovýchodní Šumavy má od roku 1960 hladina naší největší přehradní nádrže Lipno. Tam u Horní Plané, kde kdysi maloval a kreslil pestrou krajinnou mozaiku básník a prozaik šumavské př́írody Adalbert Stifter (1805-1868), zachytili podstatně jednodušší současnou vodní krajinu např́klad Josef Hodek (1888-1973) v obraze Lipenské jezero u Horní Plané (1965) či Ada Novák (1912-1990) v olejomalbě Lipno (1981). Rekreační využití - jachting na Lipně pak zobrazuje např́klad dynamicky pojatý Poslední vítr (1984) od Josefa Gregra (1938).

Antonín Smažil (1923-2011) vystavil roku 1983 v Mikulově rozsáhlý soubor akvarelů a několika olejomaleb pod názvem Pálavské metamorfózy [36]. Tyto zobrazené přeměny se však týkají více než vápencového bradla Pálavy, především nivní krajiny pod nimi. A. Smažil zobrazil jak zbytky autochtonní prírody např. Mušovské vrby (1970), Lužní lesy u Nových Mlýnů (1976) a jejich zánik Lužní lesy odcházejí (1975), tak i budování vodních nádrží - viz např. Betonárka pod Pálavou (1976) i přehradní jezera napuštěná - např. Nové zrcadlení Pálavy (1981) a Nad přehradou (1982). 


\section{Výtvarná výzdoba přehradních objektů}

Zejména v 60. až 80. letech minulého století bývaly některé stavby doplňovány výtvarnými díly. Stávalo se tak i u doprovodných objektů přehrad. Zmiňme alespoň dva prípady. S vodárenskou nádrží Kružberk na řece Moravici souvisí úpravna vody v Podhradí u Vítkova. Její hlavní budova je od roku 1967 vyzdobena komplexem kamenných reliéfư Voda v našem životě. Jedná se o poslední monumentální dílo predního českého sochaře Vincence Makovského (1900-1966).

Na stěně hydroelektrárny u výpustního objektu dolní nádrže vodního díla Nové Mlýny je již z dálky nápadný modravý reliéf (obr. 19). Jedná se o čtyřverší Jana Skácela (1922-1989), do tvaru klínu táhnoucích divokých hus ztvárněné všestranným brněnským výtvarníkem Milošem Slezákem (1921-1989). Toto čtyřverší, dráždící některé ekologické aktivisty, zní: „Divoké husy s křikem táhnou k jihu / a vodní slípky po hladině plavou. / Rozmlouvá vítr v rádkách kukuřice. / Je konec žízně v kraji pod Pálavou. "Veliký moravský básník tím vlastně přitakal rozsáhlým vodohospodářským úpravám na jižní Moravě, které jsou z pohledu i profesionálních ekologů poněkud problematické. Jan Skácel, neohrožený a v době normalizace zakázaný - básník, který si vždycky bubnoval v rytmu vlastní krve, však na svém názoru trval. Už proto, že vyrůstal v jihomoravské Poštorné, kde zažíval povodně i suchem vyprahlá pole, považoval novomlýnské nádrže nejen za užitečné, ale i za krásné [37].

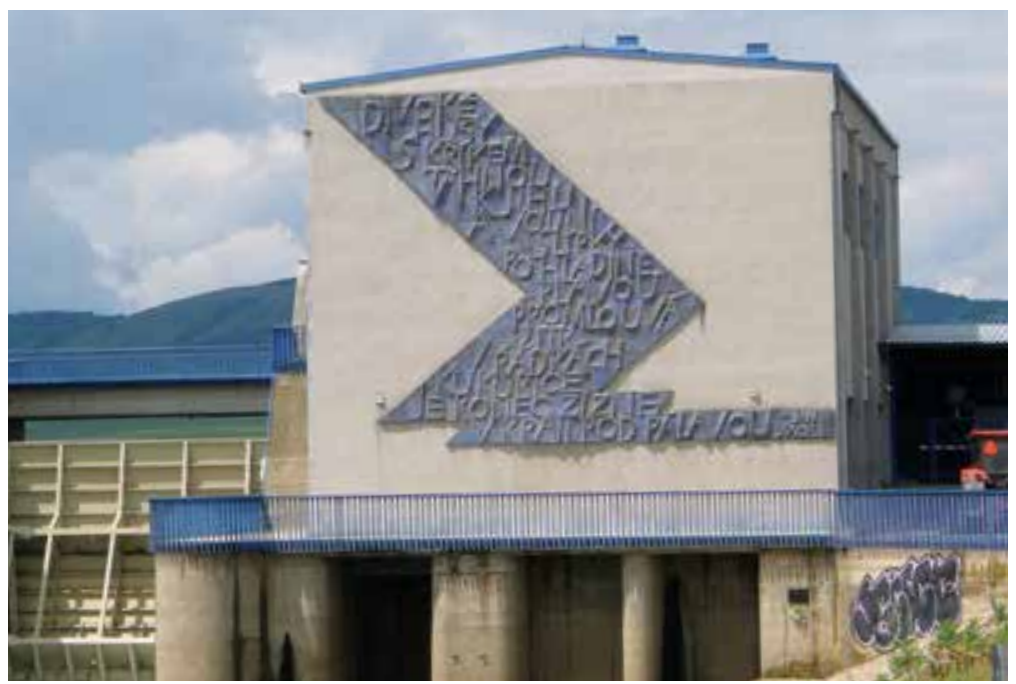

Obr. 19. Čtyřverší Jana Skácela, ztvárněné Milošem Slezákem na budově vodní elektrárny u Nových Mlýnů (80. léta 20. století)

Fig. 19. Jan Skácel's quatrian, performed by Miloš Slezák at the building of the hydroelectric power station near Nové Mlýny (1980's of the 20 $0^{\text {th }}$ century)

\section{DISKUSE A ZÁVĚR}

Může být malba či grafický list dostačujícím svědectvím o struktuře krajiny v určité době podobně jako fotografie? Porovnávání starých krajinomaleb, litografí, rytin se současným stavem kdysi zobrazené krajiny sice nemá ještě př́liš dlouhou tradici u nás ani v zahraničí, jak je patrné z malého množství obdobných prací [38-39], přesto Ize konstatovat, že ano. Autoři tohoto článku s fotografem Josefem Ptáčkem zatím vstoupili do záběru téměř 130 výtvarných děl od trri desítek malîrů a grafiků a fotograficky je zdokumentovali. Z dosavadního výzkumu vyplývá, že malîrské či grafické zobrazení krajiny dokumentuje nejen krajinný ráz, daný určitým rozložením vegetačních formací jako důsledku určitého způsobu využití půdy, ale při dostatečně podrobném realistickém zobrazení lze dokonce určit či alespoň odhadnout i zastoupení určitých rostlinných společenstev ba i konkrétních druhů. K nejcennějším pro hodnocení krajinných změn patři ta stará zobrazení krajiny, která byla tvořena ještě před vynálezem fotografie. V každém př́padě Ize krajinomalbu i grafické listy použít při hodnocení krajinných změn alespoň jako doplněk ke starým mapám a fotografiím.

Platí to samozřejmě i při rekonstrukci rázu a vegetačních formací krajinných částí, které byly dotčeny výstavbou přehrad. Protože se jednalo zpravidla o území se zvláště přitažlivou a malebnou krajinnou mozaikou, patřila tato území - jak o tom svědčí údolí Dyje a Želetavky, zatopená ve 30. letech Vranovskou přehradou - k malírsky nejfrekventovanějším. Proto je odtud k dispozici dostatek výtvarných dokumentů pro krajinně ekologickou interpretaci.

\section{Poděkování}

Děkujeme za poskytnutí reprodukčních práv ke sbírkovým předmětům Jihomoravskému muzeu ve Znojmě, príspěvkové organizaci se sídlem Přemyslovců 129/8, 66902 Znojmo. Za možnost nahlédnutí do depozitáre obrazové sbírky děkujeme pracovníkưm Regionálniáho muzea v Mikulově. Článek vznikl díky podpoře NAKI DF3P01OVV012 Zatopené kulturní a prírodni dědictví jižní Moravy a institucionální podpory Ústavu geoniky AV ČR, v. v. i. (RVO:68145535).

\section{Literatura}

[1] HAASE, D., WALZ, U., NEUBERT, M., and ROSENBERG, M. Changes to Central European landscapes Analysing historical maps to approach current environmental issues, examples form Saxony, Central Germany. Land Use Policy, 2007, 24 (1), p. 248-263.

[2] SWETNAM, R.D. Rural land use in England and Wales between 1930 and 1998: Mapping trajectories of change with a high resolution spatio-temporal dataset. Landscape and Urban Planning, 2007, 81 (1-2), p. 91-103.

[3] PALANG, H., MANDER, U., and LUUD, A. Landscape diversity changes in Estonia. Landscape and Urban Planning, 1998, 41 (3-4), p. 163-169.

[4] DEMEK, J., HAVLIČEK, M., and MACKOVČIN, P. Landscape Changes in the Dyjsko-svratecký and Dolnomoravský Grabens in the period 1764-2009 (Czech Republic). Acta Pruhoniciana, 2009, 91, p. 23-30.

[5] DEMEK, J., HAVLIČCKK, M., MACKOVČIN, P. a SLAVÍK, P. Změny ekosystémových služeb poříčních a údolních niv v České republice jako výsledek vývoje využivání země v posledních 250 letech. Acta Pruhoniciana, 2011, 98, s. 47-53.

[6] HAVLÍČEK, M., KREJČÍKOVÁ, B., CHRUDINA, Z., BOROVEC, R. a SVOBODA, J. Změny ve využití krajiny a na vodních tocích v povodí veličky a v horních povodích Kyjovky a Svratky. Acta Pruhoniciana, 2011, 99, s. 5-17.

[7] HAVLÍČEK, M., CHRUDINA, Z. a SVOBODA, J. Vývoj využití krajiny v geomorfologických celcích okresu Hodonín. Acta Pruhoniciana, 2012, 100, s. 73-86.

[8] MACKOVČIN, P., DEMEK, J. a HAVLÍČEK, M. Kulturní krajiny Brna a jeho okolí. In: Herber V. (ed.), Fyzickogeografický sborník 5. Fyzická geografie - výzkum, vzdělávání, aplikace. Masarykova univerzita, Brno, 2007, s. 63-68.

[9] MACKOVČIN, P., DEMEK, J. a SLAVÍK, P. Problém stability středoevropské kulturní krajiny v období agrární a průmyslové revoluce: príkladová studie z České republiky. Acta Pruhoniciana, 2012, 101, s. 33-40.

[10] SKOKANOVÁ, H., HAVLÍČEK, M., BOROVEC, R., DEMEK, J., et al. Development of land use and main land use change processes in the period 1836-2006: case study in the Czech Republic. Journal of maps, 2012, 8 (1), p. 88-96.

[11] GUSTAVSSON, E., LENNARTSSON, T., and EMANUELSSON, M. Land use more than 200 years ago explains current grassland plant diversity in a Swedish agricultural landscape. Biological Conservation, 2007, 138: 47-59.

[12] ROGERS, D.A., ROONEY, T.P., HAWBAKER, T.J., RADELOFF, V.C., and WALLER, D.M. Paying the Extinction Debt in Southern Wisconsin Forest Understories. Conservation Biology, 2009, 23: 1497-1506.

[13] WESCHE, K., KRAUSE, B., CULMSEE, H., and LEUSCHNER, Ch. Fifty years of change in Central European grassland vegetation: Large losses in species richness and animal-pollinated plants. Biological Conservation, 2012, 150: 76-85.

[14] BENDER, O., BOEHMER, H. J., JENS D., and SCHUMACHER, K.P. Using GIS to analyse long-term cultural landscape change in Southern Germany. Landscape and Urban Planning, 2005, 70: 111-125.

[15] SKALOŠ, J, WEBER, M., LIPSKÝ, Z., TRPÁKOVÁ, I., ŠANTRŮČKOVÁ, M., UHLÍŘOVÁ, L., and KUKLA, P. Using old military survey maps and orthophotograph maps to analyse long-term land cover changesCase study (Czech Republic). Applied Geography, 2011, 31: 426-438. 
[16] TRPÁKOVÁ, I. Krajina ve světle starých pramenů. Lesnická práce, 2013, 248 s. ISBN: 978-80-7458-053-6 [17] ŠTECH, V. V. Vojtěch Sedláček. Státní nakladatelství krásné literatury, hudby a umění, Praha, 1957, 82 s. [18] ŠTECH, V. V. O českém krajinářství. In: Česká krajina. (Katalog výstavy.) Alšova jihočeská galerie v Hluboké n. Vlt., 1969, s. 9-34.

[19] DEJMAL, I. Česká krajina od uklizenosti kvyklizenosti a zpustnutí. Katalog výstavy obrazů a fotografi "Tvár̆ naší země - krajina domova" 25. 1.-11. 3. 2001. Správa Pražského hradu, Česká komora architektů a Společnost pro trvale udržitelný život, Praha, 2011

[20] FRECER, J. Podyjí ve sbirce Jihomoravského muzea ve Znojmě. (Katalog k výstavě.), 2009, 112 s. ISBN 978-80-86974-05-7

[21] LACINA, J. Reflexečeskékrajiny vevýtvarném uměníz pohledu krajinného ekologa. In: HrnčiarováT. Mackovčin, P., Zvara, I. (eds) Atlas krajiny České republiky: 1. vydání. Průhonice: MŽP ČR a Výzkumny ústav Silva Taroucy pro krajinu a okrasné zahradnictví, v. v. i., 2009. Oddíl 8 Krajina v umění, s. 331. ISBN 978-80-85116-59- 5

[22] LACINA, J. Poznámky krajinného ekologa kzobrazení české krajiny a prírody ve výtvarném umění. In: Šmajs, J., ed.: Literatura - kultura - přrroda. (Sborník literárně filosofické konference k 200. výročí narozeni K. H. Máchy, Brno 11.-12. 11. 2010.) Brno: Obec spisovatelů, 2011, s. 195-206. ISBN 978-80-904218-8-2.

[23] LACINA, J. Krajinomalba jako výtvarný dokument krajinných struktur své doby. (Pohled krajinného ekologa.) Prostor Zlín, 2016, roč. XXIII., č. 1, s. 12-15.

[24] LACINA, J. and HALAS, P. Landscape painting in evaluation of changes in landscape. Journal of Landscape Ecology, 2015, 8 (2): 60-68.

[25] LACINA, J. a HALAS, P. Krajinomalba jako srovnávací báze změn a vývoje krajinných struktur. In: Salašová, A. Sborník abstraktů výroční konference CZ-IALE, Lednice na Mor., Zahradnická fakulta MENDELU, 2017, s. 18-19.

[26] MLEJNKOVÁ, H., DZURÁKOVÁ, M., HALAS, P., HAVLíČEK, M. a kol. Zatopené kulturní a prírodni dědictvíjižni Moravy. Brno: Výzkumný ústav vodohospodářský, T. G. Masaryka, v. v. i., 2016, 260 s. ISBN 978-80-87402-52-8

[27] UHLíR̆, J. Roman Havelka. Malî̌r Podyjí, 1877-1950. Třebíč: Muzeum Vysočiny, 2003.

[28] TOMEČEK, J. a HORŇANSKÁ, M. Rudolf Gajdoš. Výtvarné práce z let 1933-1973. Mikulov: Regionáln muzeum v Mikulově, 1973

[29] ANDRYS, J. Sladkés hořkým. Boskovice: František Šalé - Albert, 2007. ISBN 978-80-7326-112-2

[30] FANTURA, J. Karel Novák, výběr z maliriského díla. Katalog výstavy. Hodonín: Galerie výtvarného umění, 2005. ISBN 80-85015-40-4

[31] HLUŠIČKA, J. Matěj Trojan. Katalog výstavy. Praha: Galerie bratří Čapků, 1972.

[32] VOJTEK, A. a kol. Antonín Vojtek, maliřrjižníMoravy. Břeclav: moraviapress, 1994. RED: 532/59-464-94. [33] KUBIŠTA, F. Třetí členská výstava 1952. Krajské stredisko ÚSČSVU v Brně, 1952, 24 s.

[34] POSPÍ̌̌lL, L. Alois Lukášek. Nakladatelství Blok v Brně, 1978, 72 s.

[35] RAJLICH, J. Brno - černá bílá. Brno, Akademické nakladatelství CERM, 2015, 423 s. ISBN 978-80-7204-918-9.

[36] ZBOŘIL, M. (ed.) Antonín Smažil: pálavské metamorfózy. Katalog výstavy. Regionální muzeum Mikulov, Mikulov, 1983

[37] LACINA, J. Studánka Smuténka. Veronica, 1990, roč. 4, č. 1, s. $28-29$.

[38] RODEWALD, R. and LIECHTI, K. From Campagna to Arcadia: changes in the reception of terraced landscapes in art and their practical implications. Annales, Serries Historie et Sociologia, 2016, 26 (3): 363-372.

[39] RHIZOPOLOU, S. Changing mediterranean environment: irrefutable evidence form pre-industrial, unpublished scenes contemporary with a mission (1786-1787) in the Levant. Global NEST Journal, 2012 14 (4): 516-524.

\section{Autoři}

doc. Ing. Jan Lacina, CSc.

凶lacina@geonika.cz

Mgr. Petr Halas, Ph.D.

凶halas@geonika.cz

Ústav geoniky Akademie věd České republiky, v. v. i., pobočka Brno

\section{WATER RESERVOIRS AND THEIR LANDSCAPES IN VISUAL ART}

\section{LACINA, J.; HALAS, P.}

Institute of Geonics of the CAS

Keywords: landscapes - water reservoirs changes in landscape structures

One of the fundamental branches of landscape ecology is the assessment of changes in a landscape through comparisons of its state (usage) at different points in time. This typically employs maps, photographs, and aerial and satellite photography. However, important groundwork for the interpretation of landscape ecology may also be supplied by paintings and drawings of a landscape, provided they are sufficiently realistic. The construction of water reservoirs is among the human interventions that change the face of a landscape most profoundly. Before being dammed and flooded, valley and floodplain landscapes usually featured a varied and picturesque mosaic, attracting artists to favour it over other areas in their work. Typical examples are the valleys of the Dyje and Želetavka River in south-western Moravia, which were partially flooded during the construction of the Vranov Dam in the 1930's. From the early $19^{\text {th }}$ century, this romantic landscape had been portrayed by a large number of Austrian and Czech painters who captured its distinct features, often to the smallest detail. To assess the landscape changes, there thus exists a large series of landscape paintings and prints, especially lithographs, held by the Museum of South Moravia in Znojmo. Apart from the Vranov Dam, the article discusses the artistic documentation of landscape and the construction of the Vír Dam on the Svratka, the VItava reservoir cascade and system of water reservoirs of Nové Mlýny in South Moravia. The artistic decoration of reservoir structures is briefly mentioned as well.

Příspěvek prošel lektorským řízením. 